\title{
Synthesis, Derivatization, and Structural Analysis of Phosphorylated Mono-, Di-, and Trifluorinated D-Gluco-heptuloses by Glucokinase: Tunable Phosphoglucomutase Inhibition
}

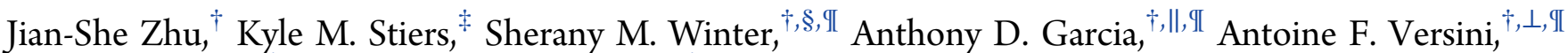
Lesa J. Beamer, $*{ }^{\dagger}$ (i) and David L. Jakeman $*,+, \#$

${ }^{\dagger}$ College of Pharmacy, Dalhousie University, 5968 College Street, Halifax, Nova Scotia B3H 4R2, Canada

${ }^{\ddagger}$ Biochemistry Department, University of Missouri, 117 Schweitzer Hall, Columbia, Missouri 65211, United States

${ }^{\S}$ Department of Chemistry, Hogeschool Leiden (UAS Leiden), Zernikedreef 11, CK Leiden 2333, The Netherlands

"École Nationale Supérieure de Chimie de Rennes, 11 Allée de Beaulieu, CS 50837, Rennes Cedex 7 35708, France

${ }^{\perp}$ École Supérieure de Physique et de Chimie Industrielles de la Ville de Paris, 10 rue Vauquelin, Paris 75005, France

\# Department of Chemistry, Dalhousie University, Halifax, Nova Scotia B3H 4R2, Canada

Supporting Information

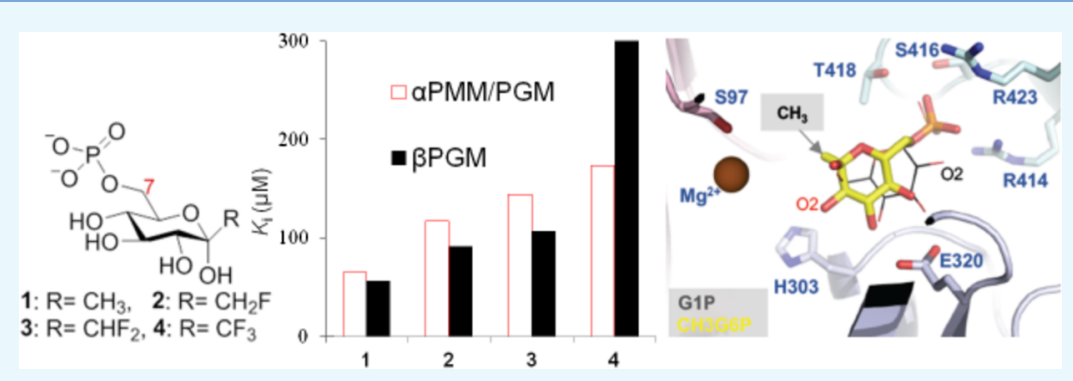

ABSTRACT: Glucokinase phosphorylated a series of C-1 fluorinated $\alpha$-D-gluco-heptuloses. These phosphorylated products were discovered to be inhibitors of $\alpha$-phosphomannomutase/phosphoglucomutase ( $\alpha$ PMM/PGM) and $\beta$-phosphoglucomutase $(\beta$ PGM $)$. Inhibition potency with both mutases inversely correlated to the degree of fluorination. Structural analysis with $\alpha$ PMM demonstrated the inhibitor binding to the active site, with the phosphate in the phosphate binding site and the anomeric hydroxyl directed to the catalytic site.

\section{INTRODUCTION}

Ketoheptoses are rare naturally occurring seven-membered sugars that are receiving increasing attention due to their potential pharmaceutical applications in the treatment of hypoglycemia or cancer. ${ }^{1}$ Ketoheptoses, especially D-mannoheptulose (Figure 1), as a substrate for noninvasive imaging of

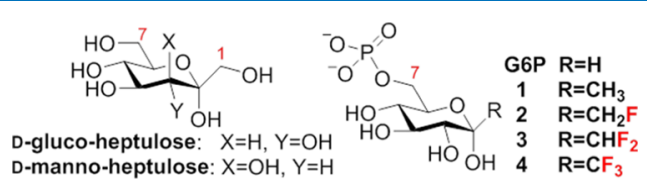

Figure 1. Representative ketoheptoses and C-1 fluorinated $\alpha$-Dglucoheptulose 7-phosphates1-4 prepared herein.

$\beta$-cells, ${ }^{1}$ provides an alternative tool in diabetes diagnosis or therapies that depend on $\beta$-cell mass visualization and quantitative analysis. ${ }^{2}$ Recently, it was found that fluorinated heptulose analogues functioned as tools for the noninvasive imaging of GLUT2-expressing insulin-producing cells by ${ }^{19} \mathrm{~F}$ magnetic resonance imaging $\left({ }^{19} \mathrm{FMRI}\right){ }^{3}$ In order to evaluate their spectrum of potential biological activities, ketoheptose analogues have been accessed by either chemical ${ }^{1,4}$ or enzymatic $^{5}$ methods, with fluorinated carbohydrates as prominent tools to study various biochemical processes including structural and mechanistic investigations, ${ }^{6}$ radiolabeling, ${ }^{7}$ lectin-carbohydrate interactions, ${ }^{8}$ and carbohydrate lipophilicity. ${ }^{9}$ Further functionalization of ketoheptoses will provide access to mechanistic probes such as C-glycosides or analogues of glucose 6-phosphate (G6P) or glucose 1phosphate (G1P). However, to date, such phosphorylated fluorinated ketoheptoses have not been prepared or evaluated. Synthetic access would provide opportunities to explore a variety of biological systems, including probing the structure and function of phosphoglucomutases (PGMs).

PGMs catalyze the reversible intramolecular conversion of G6P to G1P, and play essential biological roles in numerous living organisms from bacteria to humans. ${ }^{10}$ There are two different classes of PGMs, $\alpha$-phosphoglucomutases ( $\alpha$ PGM) and $\beta$-phosphoglucomutase ( $\beta$ PGM), differing in the substrate

Received: January 2, 2019

Accepted: April 8, 2019

Published: April 18, 2019 
anomer and enzyme mechanism of action. $\beta$ PGM from Lactococcus lactis (L. lactis), a member of haloacid dehalogenase superfamily, ${ }^{11}$ is essential in the maltose and trehalose catabolic pathway of L. lactis. ${ }^{12} \alpha$-Phosphomannomutase/ PGM ( $\alpha$ PMM/PGM) from Pseudomonas aeruginosa ( $P$. aeruginosa) belongs to the $\alpha$-D-phosphohexomutases family and has dual substrate specificity for $\alpha$-mannose 1-phosphate and $\alpha \mathrm{G} 1 \mathrm{P} .{ }^{13}$ In $P$. aeruginosa, $\alpha \mathrm{PMM} / \mathrm{PGM}$ is involved in the biosynthesis of alginate, B-band lipopolysaccharide (LPS), rhamnolipid, and the LPS-core. ${ }^{14}$ These polysaccharides are essential components of the bacterial cell wall and are implicated in $P$. aeruginosa virulence. Additionally, $P$. aeruginosa is a deadly opportunistic human pathogen listed as a significant threat by the World Health Organization. ${ }^{15}$ These data make this enzyme a potential target for antibacterial drug design.

Both enzymes share a similar mechanistic pathway, consisting of two enzymatic phosphorylations (Figure 2), ${ }^{13}$

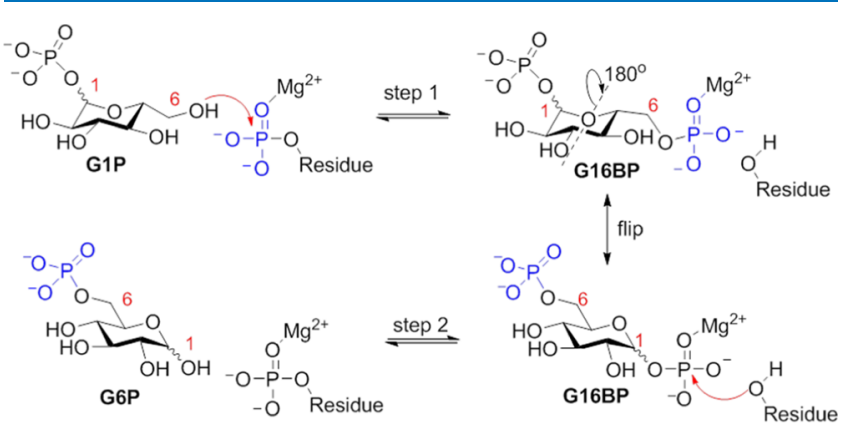

Residue $=\operatorname{Ser} 108(\alpha \mathrm{PGM})$ or Asp $8(\beta \mathrm{PGM})$

Figure 2. Reactions catalyzed by $\alpha$ - and $\beta$-PGM.

involving a single active site phosphoenzyme, which is serine (Ser) in $\alpha$ PGM and aspartic acid (Asp) in $\beta$ PGM. The first step involves the transfer of the phosphoryl group from the phosphoenzyme to the $\mathrm{C} 6-\mathrm{OH}$ group of G1P, and formation of an intermediate glucose 1,6-bisphosphate (G16BP). After reorientation and rebinding to the active site, this intermediate (step 2) is converted to product G6P by phosphoryl transfer back to the dephosphoenzyme from the $\mathrm{C} 1-\mathrm{OH}$ group, thus finishing the catalytic cycle.

Early probes into the mechanism of $\alpha$ PGM include galactose 1,6-bisphosphate ${ }^{16}$ and fructose 2,6-bisphosphate, ${ }^{17}$ as G16BP analogues, whereas 1-deoxyglucose 6-phosphate was evaluated as an inhibitor of $\alpha \mathrm{PMM} / \mathrm{PGM}$ from $P$. aeruginosa. ${ }^{18}$ Attempts to inhibit $\alpha \mathrm{PGM}$ covalently have included evaluation of sugar phosphofluoridates, sugar cyclic phosphates, ${ }^{19}$ and nojirimycin 6-phosphate. ${ }^{20}$ Metal complexes have also been studied, as mimics of the transferred phosphate, including with $\alpha \mathrm{PGM}$ and 6-vanadate- $\alpha \mathrm{G}_{1} \mathrm{P}^{21}$ and more recently with $\beta \mathrm{PGM}$ in aluminum and magnesium fluoride complexes, ${ }^{22}$ together with the $\mathrm{G}_{6} \mathrm{P}^{23}$ and with the nonhydrolyzable monofluoromethylene phosphonate substrate analogues that enabled access to the first $\beta$ PGM phosphoryl transfer step. ${ }^{24}$

Herein, we describe Escherichia coli glucokinase (Glk)catalyzed phosphorylation of a series of C-1 fluorinated $\alpha$-Dgluco-heptuloses, and evaluation of the 7-phosphates 1-4, as $\alpha \mathrm{G} 6 \mathrm{P}$ analogues, against both $\alpha$ - and $\beta$-phosphoglucomutases.

\section{RESULTS AND DISCUSSION}

It was envisioned that the $\alpha \mathrm{G} 6 \mathrm{P}$ analogues, $1-4$ could be accessible by an E. coli $\mathrm{Glk}^{25}$-catalyzed phosphorylation of the
7-OH group of the appropriate C-1 fluorinated ketoses, in turn obtained from global debenzylation of compounds, 8-11 (Scheme 1). These intermediates were all readily obtained

Scheme 1. Synthesis of (a) compound 8 and (b) 1-4

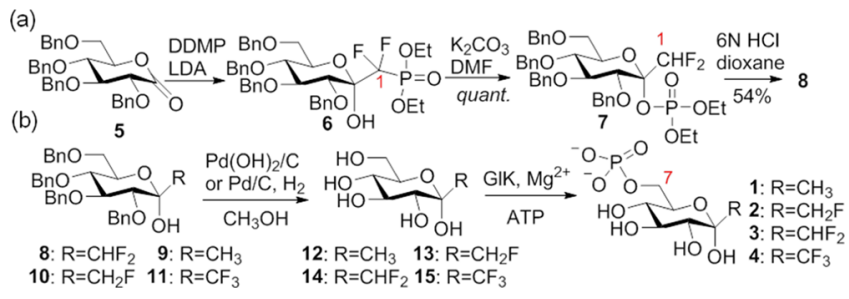

starting from protected gluconolactone 5. Methylated compound $9,^{26}$ monofluoromethylated compound $10,,^{27}$ and trifluoromethylated compound $1 \mathbf{1}^{28}$ were readily prepared, starting from $\mathbf{5}$ according to the reported procedures, where nucleophilic addition of commercially available $\mathrm{CH}_{3} \mathrm{Li}$ and $\mathrm{TMSCF}_{3}$ to 5 furnished $\mathbf{9}$ and 11, respectively. In contrast, the direct synthesis of the difluoromethylated compound $\mathbf{8}$ required a different approach due to lack of a convenient difluoromethyl nucleophile. As a result, diethyl difluoromethyl phosphonate (DDMP) ${ }^{29}$ was utilized for this purpose.

The synthesis of compound 8 (Scheme la) commenced with 6, prepared by nucleophilic addition of DDMP to $5 .^{30}$ The resultant phosphonate 6 then rearranged at $55{ }^{\circ} \mathrm{C}$ with anhydrous $\mathrm{K}_{2} \mathrm{CO}_{3}$ to yield phosphate 7 quantitatively. The rearranged structure 7 was confirmed by analysis of NMR data. In the ${ }^{1} \mathrm{H}$ NMR spectrum of 7, a new triplet signal at $6.6 \mathrm{ppm}$ was assigned as H-1. Additionally, a doublet of signals for each fluorine and a singlet signal were observed in the ${ }^{19} \mathrm{~F}\left\{{ }^{1} \mathrm{H}\right\}$ and ${ }^{31} \mathrm{P}\left\{{ }^{1} \mathrm{H}\right\}$ NMR spectra of 7 , respectively (Figure $\mathrm{S} 1$ in the Supporting Information). By comparison for 6 , the fluorine and phosphorus signals were an $A B X$ spin system and a triplet in the ${ }^{19} \mathrm{~F}\left\{{ }^{1} \mathrm{H}\right\}$ and ${ }^{31} \mathrm{P}\left\{{ }^{1} \mathrm{H}\right\} \mathrm{NMR}$, respectively, arising from ${ }^{19} \mathrm{~F}-{ }^{19} \mathrm{~F}$ and ${ }^{19} \mathrm{~F}-{ }^{31} \mathrm{P}$ coupling (Figure $\mathrm{S} 1$ in the Supporting Information). Finally, acidic hydrolysis of the phosphate group in 7 with $6 \mathrm{~N} \mathrm{HCl} / 1$,4-dioxane afforded 8 in 54\% yield, with spectroscopic data consistent with those reported. ${ }^{31}$ This method to make 8 is very efficient, on the gram scale with $40 \%$ overall yield from 5 with column chromatography only after the final step. This is the first time this rearrangement incorporates a difluoromethyl group into a carbohydrate.

Compounds 8-11 were subjected to hydrogenolysis (Scheme 1b) with either $\mathrm{Pd}(\mathrm{OH})_{2} / \mathrm{C}-\mathrm{H}_{2}$ or $\mathrm{Pd} / \mathrm{C}-\mathrm{H}_{2}$ to provide the corresponding $\alpha$-D-gluco-heptulose analogues, 1215 in quantitative yields. Compound $\mathbf{1 3}$ is known to inhibit glucose metabolism and insulin secretion and also has potential as a tracer for the noninvasive imaging of hepatocytes and insulin producing cells by ${ }^{19} \mathrm{FMRI}^{3}{ }^{3}$ Therefore, the difluoro and trifluoro compounds $\mathbf{1 4}$ and $\mathbf{1 5}$ may have similar utility.

Glk is known as a glucokinase rather than a hexokinase, which specifically phosphorylates gluco-configured substrates. $^{25}$ Analogues 12-15 were examined as substrates of Glk, utilizing conditions described in the literature. ${ }^{32}$ Recombinant Glk was found to efficiently convert all four C1 fluoromethyl-modified G1P analogues (12-15) to corresponding 7-phosphorylated products. This result demonstrates that Glk tolerates a glucopyranose sugar modified at the anomeric center. Quantitative conversion of these compounds (Scheme 1b) on a milligram scale through overnight 
incubation with Glk was achieved as observed by ${ }^{1} \mathrm{H}$ NMR or ${ }^{19} \mathrm{~F}\left\{{ }^{1} \mathrm{H}\right\}$ NMR spectra. The pure products were then isolated exclusively as $\alpha$-anomers in $73-98 \%$ yield by selective precipitation of adenosine diphosphate and adenosine triphosphate (ATP) with ethanol, followed by size exclusion chromatography. ${ }^{32}$ The observation of a doublet signal for the C-7 $\left({ }^{2} J_{\mathrm{C}-7, \mathrm{P}}=7.5 \mathrm{~Hz}\right)$ and C-6 $\left({ }^{3} J_{\mathrm{C}-7, \mathrm{P}}=4.0 \mathrm{~Hz}\right)$ due to the ${ }^{13} \mathrm{C}-{ }^{31} \mathrm{P}$ coupling in the ${ }^{13} \mathrm{C}\left\{{ }^{1} \mathrm{H}\right\}$ NMR spectra of $\mathbf{1 - 4}$ further confirmed these G6P derivative structures.

Based on the anomeric configuration, it was hypothesized that these $\alpha \mathrm{G} 6 \mathrm{P}$ analogues could be potential substrates of $\alpha \mathrm{PMM} / \mathrm{PGM}$ from $P$. aeruginosa but inhibitors of $\beta \mathrm{PGM}$ from L. lactis. We were also curious about how these enzymes would respond to the increasingly bulkier and electronegative C-1 modification from 1 to 4 . Initially compounds were evaluated as substrates. None of compounds $1-4$ proved to be substrates of either $\alpha \mathrm{PMM} / \mathrm{PGM}$ from $P$. aeruginosa or $\beta$ PGM from $L$. lactis up to a concentration of $0.2 \mathrm{mM}$, presumably due to the methyl substituent at C-1 blocking phosphoryl transfer by $\alpha \mathrm{PMM} / \mathrm{PGM}$ or $\beta \mathrm{PGM}$ (Scheme $\mathrm{S} 1$ in the Supporting Information). As a result, they were evaluated as potential inhibitors of these enzymes at various concentrations (0-1000 $\mu \mathrm{M}$ ) by measuring their $\mathrm{IC}_{50}$ values (Figure S3 and S4 in the Supporting Information) through a coupled assay, as described in the literature. ${ }^{24 b, 33}$ It was noteworthy that these analogues (1-4), although structurally similar to G6P, showed no significant inhibition against G6P dehydrogenase, the second enzyme used in the coupled assay (a maximum of $15 \%$ inhibition at $5 \mathrm{mM}$ inhibitor concentration was observed). The inhibition results of compounds 1-4 against $\alpha$ PMM/PGM and $\beta$ PGM are summarized in Table 1.

Table $1 . \mathrm{IC}_{50}$ Values of $1-4$ against $\alpha \mathrm{PMM} / \mathrm{PGM}$ from $P$. aeruginosa and $\beta$ PGM from $L$. lactis

\begin{tabular}{cccccc} 
& \multicolumn{2}{c}{$\alpha{\mathrm{PMM} / \mathrm{PGM}^{a}}$} & & \multicolumn{2}{c}{$\beta \mathrm{PGM}^{b}$} \\
\cline { 2 - 3 } \cline { 5 - 6 } compound & $\mathrm{IC}_{50}(\mu \mathrm{M})$ & $K_{\mathrm{i}}(\mu \mathrm{M})^{c}$ & & $\mathrm{IC}_{50}(\mu \mathrm{M})$ & $K_{\mathrm{i}}(\mu \mathrm{M})^{c}$ \\
$\mathbf{1}$ & $131 \pm 1$ & $65 \pm 0.5$ & & $113 \pm 3$ & $57 \pm 2$ \\
$\mathbf{3}$ & $234 \pm 29$ & $117 \pm 14$ & & $183 \pm 14$ & $92 \pm 7$ \\
4 & $288 \pm 37$ & $144 \pm 18$ & & $214 \pm 11$ & $107 \pm 6$ \\
${ }^{a} K_{\mathrm{m}}(\alpha \mathrm{G} 1 \mathrm{P})$ & $345 \pm 55$ & $174 \pm 27$ & & $621 \pm 82$ & $310 \pm 41$ \\
data. $^{34}$ & $20 \mu \mathrm{M} .{ }^{b} K_{\mathrm{m}}(\beta \mathrm{G} 1 \mathrm{P})=9 \mu \mathrm{M}^{24 \mathrm{~b}}{ }^{c}$ Calculated from $\mathrm{IC}_{50}$ \\
\hline
\end{tabular}

The $K_{\mathrm{i}}$ values were calculated based on the $\mathrm{IC}_{50}$ values, $K_{\mathrm{m}}$ and substrate concentration using the published equations. ${ }^{34}$ As the substrate concentration was equal to $K_{\mathrm{m}}$ under the assay conditions, $K_{\mathrm{i}}=1 / 2 \mathrm{IC}_{50}$ for either competitive or uncompetitive inhibitors, whereas $K_{\mathrm{i}}=\mathrm{IC}_{50}$ for the noncompetitive inhibitors. Based on the structural data (vide infra), the $\alpha \mathrm{G} 6 \mathrm{P}$ analogues $(1-4)$ were assumed to be competitive inhibitors of $\alpha \mathrm{PMM} / \mathrm{PGM}$ from $P$. aeruginosa or $\beta$ PGM from $L$. lactis, with $K_{\mathrm{i}}$ values calculated to be between 65 and $174 \mu \mathrm{M}$ for $\alpha \mathrm{PMM} /$ PGM and from 57 to $310 \mu \mathrm{M}$ for $\beta$ PGM. Interestingly, a trend was observed in that the $\mathrm{IC}_{50}$ value increased in the order 1 to 4 against $\alpha \mathrm{PMM} / \mathrm{PGM}$. This trend is in accordance with the increasing bulkiness ${ }^{35}$ and electronegativity ${ }^{36}$ of the substituent $\left(\mathrm{CH}_{3}<\mathrm{CH}_{2} \mathrm{~F}<\mathrm{CHF}_{2}<\mathrm{CF}_{3}\right)$ at the anomeric center. It was noteworthy to find that this trend was also observed in the $\beta$ PGM data, although these analogues are not in the enzymefavored $\beta$-anomeric configuration. These results demonstrate that both $\alpha \mathrm{PMM} / \mathrm{PGM}$ and $\beta \mathrm{PGM}$ activity is tunable in response to the steric component at the anomeric center of the physiological substrate, G6P.

To study the structural interactions of these G6P analogues with $\alpha \mathrm{PMM} / \mathrm{PGM}$, we utilized the protein PGM from Xanthomonas citri (XcPGM), ${ }^{13}$ a phytopathogen, known for being the causative agent of citrus canker. XcPGM is $34 \%$ identical overall in amino acid sequence to $P$. aeruginosa PMM/PGM, and active site residues in the two proteins are very highly conserved (Figure S5 in the Supporting Information). Crystals of XcPGM diffract to high resolution and are amenable to the formation of ligand complexes. ${ }^{37}$ Crystal structures of XcPGM as apo-enzymes and in complexes with G1P and G16BP were previously published (PDB IDs: $5 B M N, 5 B M P$, and 5KLO, respectively). ${ }^{37}$ These structures are used for comparisons with 1:XcPGM below.

A high-resolution structure $(1.7 \AA)$ was obtained for $\mathrm{XcPGM}$ in complex with compound 1 (PDB ID: 6N1E). Successful complex formation is consistent with the $K_{\mathrm{i}}$ of this compound (Table 1). As seen in other ligand complexes of $\mathrm{XcPGM}^{37}$ binding of $\mathbf{1}$ produces a conformational change of the protein, relative to the apo-enzyme. This involves an active site loop in the C-terminal domain (cyan in Figure 3A) of the protein (residues 415-421) that closes around the inhibitor, essentially creating a lid over the active site. Thus, $\mathbf{1}$ is deeply buried in the active site cleft, with less than $20 \%$ of its surface area exposed to solvent.

It is convenient to consider the binding modes of compound 1 relative to the interactions of XcPGM with its substrate $\alpha \mathrm{G} 1 \mathrm{P} .{ }^{37}$ As first shown in crystallographic studies of $\alpha \mathrm{PMM} /$ $\mathrm{PGM}^{38}$ binding of 1 - and 6-phosphosugars involves similar enzyme contacts to the phosphate group of the ligand, while accommodating alternate orientations of the sugar ring in the active site. This arrangement is necessitated by the $180^{\circ}$ flip of the G16BP intermediate, required by the enzyme mechanism (compare sugar ring orientation of $\alpha \mathrm{G} 1 \mathrm{P}$ and G6P in Figure 2 ). The XcPGM/1 complex provides characterization for a 6phosphosugar complex. In particular, this includes interactions with Arg414, Arg423, Asn417, Ser416, and Thr418 of the phosphate (Figure $3 \mathrm{~B}$ and Table S2), that is, the same residues used for phosphate binding in $\alpha \mathrm{G} 1 \mathrm{P}$.

By contrast, interactions with the hydroxyls of the sugar ring vary significantly due to the alternate orientation of the sugar ring. Glu320 is able to maintain a key bidentate interaction with $\mathrm{O} 3$ and $\mathrm{O} 4$ because these hydroxyls essentially exchange places (Figure 3B). However, the backbone amide of His303 contacts $\mathrm{O} 3$ in the 1 complex, instead of $\mathrm{O} 4$ as in the G1P complex (Table S2). Other changes include loss of an interaction between Arg280 and O2 due to its distinct position in the $\mathbf{1}$ complex. ${ }^{38}$ Overall, it appears that inhibitor $\mathbf{1}$ utilizes the expected binding interactions of a 6-phosphosugar with the enzyme, despite replacing the anomeric hydrogen atom with a methyl substituent. There are no protein atoms within $4.5 \AA$ of this methyl group. Owing to the shared phosphate binding interactions with both G1P and $\mathbf{1}$, the observed binding mode is consistent with competitive inhibition (Table 1).

\section{CONCLUSIONS}

In conclusion, synthetic access to four C-1 fluorinated $\alpha$-Dgluco-heptulose analogues was accomplished through chemical manipulations of gluconolactone 5. Derivatizing these heptulose analogues by E. coli Glk led to corresponding $\alpha$-Dgluco-heptulose 7-phosphate analogues 1-4 that are inhibitors of both $\alpha \mathrm{PMM} / \mathrm{PGM}$ and $\beta \mathrm{PGM}$. Inhibition potency against 

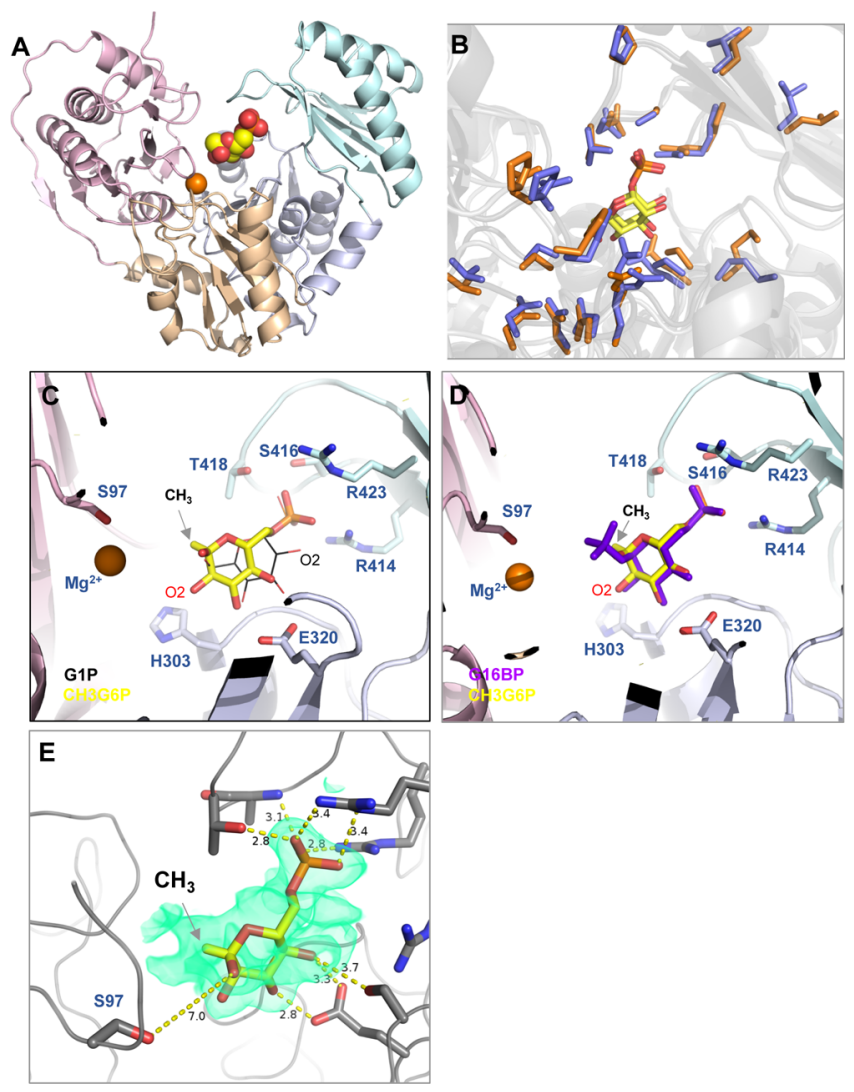

Figure 3. (A) Crystal structure of the XcPGM complex with inhibitor 1 (PDB 6N1E). Ligand is shown as a space-filling model; bound $\mathrm{Mg}^{2+}$ ion as an orange sphere. The protein is colored by domains as pink, beige, gray-blue, and cyan. (B) Structural superposition of $X$. citri $\alpha \mathrm{PGM}$ (orange) and P. aeruginosa $\alpha \mathrm{PMM} / \mathrm{PGM}$ (blue), both in complex with substrate G1P (yellow). Side chains of identical residues are shown as sticks. Note the overall structural similarity of both polypeptide backbone and active-site side chains. (C) Close-up view of the active site showing a superposition of 1 (yellow) with G1P (black) from the substrate complex of XcPGM (PDB ID 5BMP). (D) Close-up view of the active site showing a superposition of $\mathbf{1}$ (yellow) with G16BP (purple) from the intermediate complex of XcPGM (PDB ID 5KL0). (E) Polder-style omit map showing the ligandbinding site in the enzyme-CH3G6P complex. Electron density (green) is contoured at $3.0 \sigma$. Residues involved in interactions with ligands are shown as sticks. Hydrogen bond lengths and the distance from Ser97 to $\mathrm{O} 1$ of $\mathbf{1}$ are indicated.

both enzymes is dependent on the size and electronegativity of the substituted group at C-1 position, with the C-1 methylated G6P analogue (1), displaying the most significant inhibition. Both enzymes were found to be sensitive to the steric and electronic environment at the anomeric center of G6P. X-ray crystallographic analysis of $\mathbf{1}$ with XcPGM demonstrates that this inhibitor occupies the enzyme active site and that the methyl substituent does not form specific contacts with activesite residues. These structural insights will guide future potential antibacterial drug design targeting $P$. aeruginosa $\alpha \mathrm{PMM} / \mathrm{PGM}$ and will be reported in due course.

\section{EXPERIMENTAL SECTION}

General Methods and Instrumentation for Chemical Synthesis. All chemicals and reagents were purchased and used as received, unless noted otherwise. Anhydrous reaction conditions were maintained under an inert atmosphere of dried high-purity nitrogen. Glassware was dried overnight in an oven at $120{ }^{\circ} \mathrm{C}$ and assembled under a stream of inert nitrogen. Thin layer chromatography plates were visualized by ultraviolet light at 254 and/or by charring after treatment with Vanillin stain. Flash chromatography was performed with silica gel 60 (230-400 mesh). Lyophilization of samples was carried out using a freeze-dryer. NMR spectra were recorded on a Bruker 300 or $500 \mathrm{MHz}$ spectrometers. All ${ }^{1} \mathrm{H},{ }^{13} \mathrm{C},{ }^{19} \mathrm{~F}$, and ${ }^{31} \mathrm{P}$ chemical shifts are reported in $\mathrm{ppm}$ using tetramethylsilane $(0.00 \mathrm{ppm})$ or the solvent signal $\left[\mathrm{CDCl}_{3}\left({ }^{1} \mathrm{H} 7.26 \mathrm{ppm} ;{ }^{13} \mathrm{C}\right.\right.$ $\left.77.16 \mathrm{ppm}) ; \mathrm{D}_{2} \mathrm{O}\left({ }^{1} \mathrm{H} 4.79 \mathrm{ppm}\right)\right]$ as the internal reference or MeOD $\left({ }^{13} \mathrm{C} 49.50 \mathrm{ppm}\right.$ in $\left.\mathrm{D}_{2} \mathrm{O}\right)$ or $85 \%$ aq $\mathrm{H}_{3} \mathrm{PO}_{4}\left({ }^{31} \mathrm{P} 0.00\right.$ $\mathrm{ppm})$ as an external reference. Splitting patterns are indicated as follows: br, broad; s, singlet; $d$, doublet; $t$, triplet; at, apparent triplet; q, quartet; m, multiplet. All coupling constants $(J)$ are reported in hertz $(\mathrm{Hz})$. Mass spectra were recorded using ion trap (ESI TOF) instruments.

General Procedure: Glk-Catalyzed Synthesis of 7Phospho Analogues. This followed the literature procedure with minor modifications. ${ }^{32}$ A final volume of $4 \mathrm{~mL}(50 \mathrm{mM}$ Tris-HCl, $\mathrm{pH}$ 7. 5) comprising 1-deoxy- $\alpha$-D-glucoheptuloses $(50 \mu \mathrm{M}), \mathrm{MgCl}_{2}(102 \mathrm{mg}, 500 \mu \mathrm{M})$, ATP $(200 \mathrm{mM}, 500 \mu \mathrm{L})$, and recombinant E. coli Glk $\left(28 \mathrm{mg} \mathrm{mL}^{-1}, 110 \mu \mathrm{L}\right)$ was incubated at $37^{\circ} \mathrm{C}$ overnight.

The reaction mixture was quenched by the addition of three volumes of ethanol, followed by centrifugation at $5000 \mathrm{~g}$ for $1 \mathrm{~h}$ at $4{ }^{\circ} \mathrm{C}$. The supernatant was collected, and the solvent was evaporated in vacuo. The above manipulation was repeated once by re-dissolving the resultant material in millipore water $(1 \mathrm{~mL})$ and ethanol $(9 \mathrm{~mL})$. The resulting residue was then redissolved in $0.6 \mathrm{~mL}$ of distilled water and desalted by size exclusion chromatography (Sephadex LH20) eluting with millipore water. Fractions containing the product were collected, concentrated, and lyophilized.

1-Deoxy- $\alpha$-D-gluco-heptulose 7-Phosphate (1). Lactone 5 was prepared from commercially available 2,3,4,6-tetra-Obenzyl glucopyranose, following a known procedure, ${ }^{30}$ and then converted to 9 following a procedure described in the literature. ${ }^{26}$ To a solution of compound $9(100 \mathrm{mg}, 0.18$ $\mathrm{mmol})$ in $\mathrm{CH}_{3} \mathrm{OH}$ was added $20 \%$ wt $\mathrm{Pd}(\mathrm{OH})_{2} / \mathrm{C}(30 \mathrm{mg})$. The suspension was degassed under vacuum and saturated with $\mathrm{H}_{2}$ in a Parr Shaker at $60 \mathrm{psi}$ pressure. This reaction mixture was shaken overnight. When the starting material disappeared completely, as determined by TLC monitoring, the catalyst was removed by filtration. The filtrate was concentrated under reduced pressure to give 12 (35 mg, $100 \%)$.

Data for Compound 9 (Figure S7). ${ }^{1} \mathrm{H}$ NMR $(500 \mathrm{MHz}$, $\left.\mathrm{D}_{2} \mathrm{O}\right): \delta 7.41-7.21(\mathrm{~m}, 20 \mathrm{H}), 5.01-4.86(\mathrm{~m}, 4 \mathrm{H}), 4.78-4.56$ (m, 4H), 4.10-4.00 (m, 2H), 3.81-3.68 (m, 3H), 3.44-3.41 $(\mathrm{m}, 1 \mathrm{H}), 2.79(\mathrm{~s}, \mathrm{br}, 1 \mathrm{H}, \mathrm{OH})$, and $1.47(\mathrm{~s}, 3 \mathrm{H})$. This is consistent with the reported data. ${ }^{39}$

Data for Compound 12 (Figures S8 and S9). ${ }^{1} \mathrm{H}$ NMR $\left(500 \mathrm{MHz}, \mathrm{D}_{2} \mathrm{O}\right): \delta 3.79(\mathrm{dd}, J=11.5$ and $2.0 \mathrm{~Hz}, 1 \mathrm{H}), 3.76-$ $3.68(\mathrm{~m}, 2 \mathrm{H}), 3.61(\mathrm{t}, J=9.5 \mathrm{~Hz}, 1 \mathrm{H}), 3.35(\mathrm{t}, J=9.5 \mathrm{~Hz}$, $1 \mathrm{H})$, and $3.24(\mathrm{~d}, J=9.5 \mathrm{~Hz}, 1 \mathrm{H}) .{ }^{13} \mathrm{C}$ NMR $(125 \mathrm{MHz}$, $\left.\mathrm{D}_{2} \mathrm{O}\right): \delta 97.5,75.1,73.6,72.3,69.9,60.7$, and 24.6. HRMS $\left(\mathrm{ESI}^{+}\right)$: found $[\mathrm{M}+\mathrm{Na}]^{+}, 217.0692, \mathrm{C}_{7} \mathrm{H}_{14} \mathrm{NaO}_{6}$; requires $[\mathrm{M}$ $+\mathrm{Na}]^{+}, 217.0683$.

Following the general procedure, $1(18 \mathrm{mg}, 86 \%)$ was obtained from compound $12(15 \mathrm{mg}, 31 \mu \mathrm{M}), \mathrm{MgCl}_{2}(63 \mathrm{mg}$, $310 \mu \mathrm{M})$, ATP $(200 \mathrm{mM}, 310 \mu \mathrm{L})$, Glk $\left(28 \mathrm{mg} \mathrm{mL}^{-1}, 72 \mu \mathrm{L}\right)$, and Tris $-\mathrm{HCl}(50 \mathrm{mM}, 3618 \mu \mathrm{L}, \mathrm{pH} 7.5)$. 
Data for Compound 1 (Figures $\mathrm{S} 10$ and S12). ${ }^{1} \mathrm{H}$ NMR $\left(500 \mathrm{MHz}, \mathrm{D}_{2} \mathrm{O}\right): \delta 4.05-3.95(\mathrm{~m}, 2 \mathrm{H}), 3.85-3.83(\mathrm{~m}, 1 \mathrm{H})$, $3.63(\mathrm{t}, J=5.0 \mathrm{~Hz}, 1 \mathrm{H}), 3.48(\mathrm{t}, J=5.0 \mathrm{~Hz}, 1 \mathrm{H}), 3.28-3.26$ $(\mathrm{m}, 1 \mathrm{H})$, and $1.43(\mathrm{~s}, 3 \mathrm{H}),{ }^{31} \mathrm{P}\left\{{ }^{1} \mathrm{H}\right\} \operatorname{NMR}\left(202 \mathrm{MHz}, \mathrm{D}_{2} \mathrm{O}\right): \delta$ 1.8. ${ }^{13} \mathrm{C}\left\{{ }^{1} \mathrm{H}\right\}$ NMR $\left(125 \mathrm{MHz}, \mathrm{D}_{2} \mathrm{O}\right): \delta 97.7,75.1,73.4,71.57$ $\left(\mathrm{d},{ }^{2} J_{\mathrm{C}-7, \mathrm{P}}=7.5 \mathrm{~Hz}\right), 69.4,63.7\left(\mathrm{~d},{ }^{3} J_{\mathrm{C}-6, \mathrm{P}}=4.3 \mathrm{~Hz}\right)$, and 24.5 . HRMS $\left(\mathrm{ESI}^{-}\right)$: found $[\mathrm{M}-\mathrm{H}]^{-}, 273.0379, \mathrm{C}_{7} \mathrm{H}_{14} \mathrm{O}_{9} \mathrm{P}$; requires $[\mathrm{M}-\mathrm{H}]^{-}, 273.0381$.

1-Deoxy-1-monofluoro- $\alpha$-D-gluco-heptulose 7-Phosphate (2). Subject to a two-step transformation to generate compound $\mathbf{1 0}$ in $62 \%$ yield over two steps. ${ }^{27}$ Data for $\mathbf{1 0}$ (Figure S13): ${ }^{19} \mathrm{~F}$ NMR (470 MHz, DMSO- $\left.d_{6}\right):-226.2(t$, $\left.{ }^{2} J_{\mathrm{F}, \mathrm{H}}=47.3 \mathrm{~Hz}\right)$. This is consistent with the reported data. ${ }^{27}$

To a solution of $\mathbf{1 0}(92 \mathrm{mg}, 0.16 \mathrm{mmol})$ in $\mathrm{CH}_{3} \mathrm{OH}$ was added $20 \%$ wt $\mathrm{Pd}(\mathrm{OH})_{2} / \mathrm{C}(20 \mathrm{mg})$. The suspension was degassed under vacuum and saturated with $\mathrm{H}_{2}$ under 1 atm pressure (balloon). This reaction mixture was stirred overnight. When the starting material disappeared completely, as determined by TLC monitoring, the catalyst was filtered off and the filtrate was concentrated under reduced pressure to give 13 (34 mg, 100\%). Data for 13 (Figure S14): ${ }^{19}$ F NMR $\left(470 \mathrm{MHz}, \mathrm{D}_{2} \mathrm{O}\right):-231.2\left(\mathrm{t},{ }^{2} J_{\mathrm{F}, \mathrm{H}}=47.3 \mathrm{~Hz}\right)$. This data is consistent with the reported data.

Following the general procedure, $2(10 \mathrm{mg}, 73 \%)$ was obtained from compound $13(10.0 \mathrm{mg}, 47 \mu \mathrm{M}), \mathrm{MgCl}_{2}$ (96 mg, $470 \mu \mathrm{M})$, ATP $(200 \mathrm{mM}, 472 \mu \mathrm{L})$, Glk $\left(28 \mathrm{mg} \mathrm{mL}^{-1}, 110\right.$ $\mu \mathrm{L})$, and Tris- $\mathrm{HCl}(50 \mathrm{mM}, 3418 \mu \mathrm{L}, \mathrm{pH} 7.5)$.

Data for 2 (Figures S15-S18). ${ }^{1} \mathrm{H}$ NMR (500 MHz, $\left.\mathrm{D}_{2} \mathrm{O}\right)$ : $\delta 4.50\left(\mathrm{dd},{ }^{2} J_{\mathrm{H} 1 \mathrm{a}, \mathrm{F}}=45.0 \mathrm{~Hz},{ }^{2} J_{\mathrm{H} 1 \mathrm{a}, \mathrm{H} 1 \mathrm{~b}}=10.0 \mathrm{~Hz}, 1 \mathrm{H}\right), 4.35$ $\left(\mathrm{dd},{ }^{2} \mathrm{~J}_{\mathrm{H} 1 \mathrm{~b}, \mathrm{~F}}=50.0 \mathrm{~Hz},{ }^{2} \mathrm{~J}_{\mathrm{H} 1 \mathrm{a}, \mathrm{H} 1 \mathrm{~b}}=10.0 \mathrm{~Hz}, 1 \mathrm{H}\right), 4.03-3.99(\mathrm{~m}$, $1 \mathrm{H}), 3.93$ (ddd, $J=7.5,5.5$, and $2.0 \mathrm{~Hz}, 1 \mathrm{H}), 3.89-3.86(\mathrm{~m}$, $1 \mathrm{H}), 3.74(\mathrm{t}, J=10.0 \mathrm{~Hz}, 1 \mathrm{H})$, and $3.57-3.51(\mathrm{~m}, 2 \mathrm{H})$. ${ }^{19} \mathrm{~F}\left\{{ }^{1} \mathrm{H}\right\}$ NMR $\left(470 \mathrm{MHz}, \mathrm{D}_{2} \mathrm{O}\right): \delta-231.2 .{ }^{19} \mathrm{~F}$ NMR (470 $\left.\mathrm{MHz}, \mathrm{D}_{2} \mathrm{O}\right): \delta-231.2\left(\mathrm{t},{ }^{2} J_{\mathrm{Hla}, \mathrm{H} 1 \mathrm{~b}, \mathrm{~F}}=46.8 \mathrm{~Hz}\right) \cdot{ }^{31} \mathrm{P}\left\{{ }^{1} \mathrm{H}\right\} \mathrm{NMR}$ $\left(202 \mathrm{MHz}, \mathrm{D}_{2} \mathrm{O}\right): \delta 4.1 .{ }^{13} \mathrm{C}\left\{{ }^{1} \mathrm{H}\right\} \operatorname{NMR}\left(125 \mathrm{MHz}, \mathrm{D}_{2} \mathrm{O}\right): \delta$ $96.4\left(\mathrm{~d},{ }^{2} J_{\mathrm{C}-2, \mathrm{~F}}=21.3 \mathrm{~Hz}\right), 83.2\left(\mathrm{~d},{ }^{1} J_{\mathrm{C}-1, \mathrm{~F}}=174.4 \mathrm{~Hz}\right), 73.1$, $72.2\left(\mathrm{~d},{ }^{2} J_{\mathrm{C}-7, \mathrm{P}}=7.5 \mathrm{~Hz}\right), 70.4,69.2$, and $62.9\left(\mathrm{~d},{ }^{3} J_{\mathrm{C}-6, \mathrm{P}}=4.0\right.$ $\mathrm{Hz})$. HRMS $\left(\mathrm{ESI}^{-}\right)$: found $[\mathrm{M}-\mathrm{H}]^{-}, 291.0274, \mathrm{C}_{7} \mathrm{H}_{13} \mathrm{FO}_{9} \mathrm{P}$; requires $[\mathrm{M}-\mathrm{H}]^{-}, 291.0287$.

1-Deoxy-1,1-difluoro- $\alpha$-D-gluco-heptulose 7-Phosphate (3). To a solution of freshly distilled diisopropylamine $(0.80$ $\mathrm{mL}, 5.74 \mathrm{mmol})$ in anhydrous THF $(4.5 \mathrm{~mL})$ at $-78{ }^{\circ} \mathrm{C}$ was added dropwise $n$-BuLi (2.3 mL, $2.5 \mathrm{M}$ in hexane, $5.74 \mathrm{mmol}$ ) under $\mathrm{N}_{2}$. The solution was stirred for $30 \mathrm{~min}$, allowed to warm to $0{ }^{\circ} \mathrm{C}$, and stirred for an additional $30 \mathrm{~min}$. The solution was then cooled to $-78{ }^{\circ} \mathrm{C}$. A solution of diethyldifluoromethylphosphonate $(0.87 \mathrm{~mL}, 5.55 \mathrm{mmol})$ in anhydrous THF ( $1 \mathrm{~mL})$ was added dropwise. The solution was stirred for $25 \mathrm{~min}$ and $5(1.00 \mathrm{~g}, 1.85 \mathrm{mmol})$ in anhydrous THF ( $5 \mathrm{~mL}$ ) was added dropwise. The solution was stirred for $30 \mathrm{~min}$ at $-78{ }^{\circ} \mathrm{C}$. When the reaction was complete, as determined by TLC monitoring, it was quenched by the addition of saturated aq $\mathrm{NH}_{4} \mathrm{Cl}(3 \mathrm{~mL})$ and diethyl ether (50 $\mathrm{mL})$. The aqueous layer was further extracted with diethyl ether $(3 \times 15 \mathrm{~mL})$. The combined organic layers were dried with anhydrous $\mathrm{MgSO}_{4}$, filtered, and evaporated under reduced pressure. The residue obtained was used in the next step without further purification. An analytic amount of pure sample was obtained by silica gel flash chromatography ( $n$ hexane $/$ EtOAc $=4)$ for characterization purposes.

Data for 6 (Figures S19-S21). ${ }^{1} \mathrm{H}$ NMR (500 MHz, $\left.\mathrm{CDCl}_{3}\right): \delta 7.44-7.28(\mathrm{~m}, 20 \mathrm{H}), 5.04-4.92(\mathrm{~m}, 5 \mathrm{H}), 4.69(\mathrm{~d}, J$ $=11.0 \mathrm{~Hz}, 1 \mathrm{H}), 4.63(\mathrm{~d}, J=11.9 \mathrm{~Hz}, 1 \mathrm{H}), 4.54$ (d, $J=11.9$
$\mathrm{Hz}, 1 \mathrm{H}), 4.46-4.33(\mathrm{~m}, 4 \mathrm{H}), 4.26-4.23(\mathrm{~m}, 1 \mathrm{H}), 4.20(\mathrm{t}, J=$ $9.3 \mathrm{~Hz}, 1 \mathrm{H}), 4.11-4.09(\mathrm{~m}, 1 \mathrm{H}), 3.91(\mathrm{dd}, J=11.1$ and 3.9 $\mathrm{Hz}, 1 \mathrm{H}), 3.84(\mathrm{t}, J=9.6 \mathrm{~Hz}, 1 \mathrm{H}), 3.78(\mathrm{dd}, J=11.0$ and 1.4 $\mathrm{Hz}, 1 \mathrm{H}), 1.46(\mathrm{t}, J=7.1 \mathrm{~Hz}, 3 \mathrm{H})$, and $1.38(\mathrm{t}, J=7.1 \mathrm{~Hz}, 3 \mathrm{H})$. ${ }^{19} \mathrm{~F}$ NMR (470 MHz, $\left.\mathrm{CDCl}_{3}\right): \delta-119.5\left(\mathrm{ABX},{ }^{2} J_{\mathrm{F}, \mathrm{F}}=303.7\right.$ $\left.\mathrm{Hz},{ }^{2} \mathrm{~J}_{\mathrm{F}, \mathrm{P}}=95.5 \mathrm{~Hz}\right),-120.3\left(\mathrm{ABX},{ }^{2} \mathrm{~J}_{\mathrm{F}, \mathrm{F}}=303.7 \mathrm{~Hz},{ }^{2} \mathrm{~J}_{\mathrm{F}, \mathrm{P}}=\right.$ 99.1 Hz). ${ }^{31} \mathrm{P}\left\{{ }^{1} \mathrm{H}\right\} \operatorname{NMR}\left(202 \mathrm{MHz}, \mathrm{CDCl}_{3}\right): \delta 6.6\left(\mathrm{t},{ }^{2} J_{\mathrm{P}, \mathrm{F}}=\right.$ $96.2 \mathrm{~Hz})$. This data is consistent with those reported. ${ }^{30}$

Crude 6 and anhydrous $\mathrm{K}_{2} \mathrm{CO}_{3}(1.40 \mathrm{~g}, 10.18 \mathrm{mmol})$ were dissolved in anhydrous DMF $(25 \mathrm{~mL})$. The mixture was stirred at $55{ }^{\circ} \mathrm{C}$ under $\mathrm{N}_{2}$. When the reaction was finished (about 3 $\mathrm{h}$ ), as determined by TLC analysis, it was cooled to room temperature, $\mathrm{H}_{2} \mathrm{O}(15 \mathrm{~mL})$ was added, and the product was extracted with diethyl ether $(4 \times 50 \mathrm{~mL})$. The combined organic extract was rinsed with $\mathrm{H}_{2} \mathrm{O}(1 \times 10 \mathrm{~mL})$, dried using anhydrous $\mathrm{MgSO}_{4}$, filtered, and evaporated under reduced pressure. The obtained residue was purified by silica gel flash chromatography with $n$-hexane/EtOAc $(3: 1 \mathrm{v} / \mathrm{v})$ to give 7 ( $1.16 \mathrm{~g}, 86 \%$ over two steps) as a colorless oil.

Data for 7 (Figures S22-S25). ${ }^{1} \mathrm{H}$ NMR $(500 \mathrm{MHz}$, $\left.\mathrm{CDCl}_{3}\right): \delta 7.44-7.28(\mathrm{~m}, 20 \mathrm{H}), 6.57\left(\mathrm{t},{ }^{2} J_{\mathrm{H}-1, \mathrm{~F}}=54 \mathrm{~Hz}, \mathrm{H}-1\right)$, 4.97-4.89 (m, 5H), 4.73-4.71 (m, $2 \mathrm{H}), 4.63-4.61(\mathrm{~m}, 1 \mathrm{H})$, 4.24-4.16 (m, 5H), $4.09(\mathrm{t}, J=9.4 \mathrm{~Hz}, 1 \mathrm{H}), 4.01(\mathrm{dd}, J=9.4$ and $4.0 \mathrm{~Hz}, 1 \mathrm{H}), 3.92(\mathrm{dd}, J=11.5$ and $3.6 \mathrm{~Hz}, 1 \mathrm{H}), 3.88(\mathrm{t}, J$ $=9.7 \mathrm{~Hz}, 1 \mathrm{H}), 3.81(\mathrm{dd}, J=11.4$ and $1.6 \mathrm{~Hz}, 1 \mathrm{H})$, and $1.38-$ $1.32(\mathrm{~m}, 6 \mathrm{H}) \cdot{ }^{19} \mathrm{~F}\left\{{ }^{1} \mathrm{H}\right\}$ NMR $\left(470 \mathrm{MHz}, \mathrm{CDCl}_{3}\right): \delta-131.6$ $\left(\mathrm{d},{ }^{2} J_{\mathrm{F}, \mathrm{F}}=285.9 \mathrm{~Hz}\right)$ and $-133.7\left(\mathrm{~d},{ }^{2} J_{\mathrm{F}, \mathrm{F}}=285.9 \mathrm{~Hz}\right) \cdot{ }^{19} \mathrm{~F}$ NMR (470 MHz, $\left.\mathrm{CDCl}_{3}\right): \delta-131.6\left(\mathrm{~d},{ }^{2} J_{\mathrm{F}, \mathrm{F}}=285.9 \mathrm{~Hz}\right.$, $\left.{ }^{2} J_{\mathrm{H}-1, \mathrm{~F}}=53.7 \mathrm{~Hz}\right)$ and $-133.7\left(\mathrm{~d},{ }^{2} J_{\mathrm{F}, \mathrm{F}}=285.9 \mathrm{~Hz},{ }^{2} J_{\mathrm{H}-1, \mathrm{~F}}=\right.$ $55.6 \mathrm{~Hz}) .{ }^{31} \mathrm{P}\left\{{ }^{1} \mathrm{H}\right\} \quad \mathrm{NMR}\left(202 \mathrm{MHz}, \mathrm{CDCl}_{3}\right): \delta-5.85$. ${ }^{13} \mathrm{C}\left\{{ }^{1} \mathrm{H}\right\}$ NMR $\left(125 \mathrm{MHz}, \mathrm{CDCl}_{3}\right): \delta 140.4,140.2,140.0$, $139.9,130.5,130.4,130.2,130.0,129.9,129.87,129.8,129.7$, $114.4\left(\mathrm{t},{ }^{1} J_{\mathrm{C}-1, \mathrm{~F}}=248.5 \mathrm{~Hz}, \mathrm{C}-1\right), 102.8\left(\mathrm{dt},{ }^{2} J_{\mathrm{C}-2, \mathrm{~F}}=25.2 \mathrm{~Hz}\right.$, $\left.{ }^{2} J_{\mathrm{C}-2, \mathrm{P}}=8.4 \mathrm{~Hz}, \mathrm{C}-2\right), 84.4,79.95(\mathrm{~d}, J=7.1 \mathrm{~Hz}), 79.4,79.1$, 79.0, 77.2, 75.5, 70.0, $66.4\left(\mathrm{~d},{ }^{2} \mathrm{~J}_{-\mathrm{OCH}_{2} \mathrm{CH}_{3}, \mathrm{P}}=5.8 \mathrm{~Hz}\right), 66.3(\mathrm{~d}$, $\left.{ }^{2} J_{-\mathrm{OCH}_{2} \mathrm{CH}_{3}, \mathrm{P}}=5.7 \mathrm{~Hz}\right), 18.1\left(\mathrm{~d},{ }^{3} \mathrm{~J}_{-\mathrm{OCH}_{2} \mathrm{CH}_{3}, \mathrm{P}}=6.8 \mathrm{~Hz}\right)$, and $18.0\left(\mathrm{~d},{ }^{3} \mathrm{~J}_{-\mathrm{OCH}_{2} \mathrm{CH}_{3}, \mathrm{P}}=6.8 \mathrm{~Hz}\right)$.

A solution of $7(700 \mathrm{mg}, 0.96 \mathrm{mmol})$ in 1,4-dioxane $(3 \mathrm{~mL})$ and $6 \mathrm{~N} \mathrm{HCl}(3 \mathrm{~mL})$ was refluxed at $100{ }^{\circ} \mathrm{C}$ overnight. The reaction was complete as determined by TLC monitoring. The solvent was evaporated in vacuo to give a residue which was dissolved in EtOAc $(100 \mathrm{~mL})$ and washed with saturated aq $\mathrm{NaHCO}_{3}(15 \mathrm{~mL})$. The organic layer was washed with $\mathrm{H}_{2} \mathrm{O}(2$ $\times 10 \mathrm{~mL})$, then with brine $(5 \mathrm{~mL})$. The combined aqueous layer was further extracted with EtOAc $(4 \times 15 \mathrm{~mL})$. The combined organic layer was dried over $\mathrm{MgSO}_{4}$, filtered, and evaporated under reduced pressure. The residue obtained was purified by silica gel flash chromatography with $n$-hexane/ EtOAc $(6: 1 \mathrm{v} / \mathrm{v})$ to give $8(307 \mathrm{mg}, 54 \%$ yield) as a light yellow oil.

Data for 8 (Figures S26 and S27). ${ }^{1} \mathrm{H}$ NMR (500 MHz, $\left.\mathrm{CDCl}_{3}\right): \delta 7.34-7.14(\mathrm{~m}, 20 \mathrm{H}), 5.61\left(\mathrm{t},{ }^{2} J_{\mathrm{H}-1, \mathrm{~F}}=55 \mathrm{~Hz}, 1 \mathrm{H}\right)$, 4.87-4.50 (m, 8H), $4.00(\mathrm{~m}, 1 \mathrm{H}), 3.93(\mathrm{~m}, 1 \mathrm{H}), 3.84-3.77$ $(\mathrm{m}, 2 \mathrm{H}), 3.75-3.66(\mathrm{~m}, 2 \mathrm{H})$, and $3.52(\mathrm{~s}, \mathrm{br}, 1 \mathrm{H}, \mathrm{OH})$. ${ }^{19} \mathrm{~F}\left\{{ }^{1} \mathrm{H}\right\}$ NMR (470 MHz, $\left.\mathrm{CDCl}_{3}\right): \delta-133.4\left(\mathrm{~d},{ }^{2} J_{\mathrm{Fa}, \mathrm{Fb}}=283\right.$ $\mathrm{Hz})$ and $-136.4\left(\mathrm{~d},{ }^{2} J_{\mathrm{Fa}, \mathrm{Fb}}=283 \mathrm{~Hz}\right) \cdot{ }^{19} \mathrm{~F} \mathrm{NMR}(470 \mathrm{MHz}$, $\left.\mathrm{CDCl}_{3}\right): \delta-133.4\left(\mathrm{dd},{ }^{2} J_{\mathrm{Fa}, \mathrm{Fb}}=283 \mathrm{~Hz},{ }^{2} J_{\mathrm{Fa}, \mathrm{H}-1}=55 \mathrm{~Hz}\right)$ and $-136.4\left(\mathrm{dd},{ }^{2} J_{\mathrm{Fb}, \mathrm{Fa}}=283 \mathrm{~Hz},{ }^{2} J_{\mathrm{Fb}, \mathrm{H}-1}=56 \mathrm{~Hz}\right)$. These data are consistent with those reported.

To a solution of $8(50 \mathrm{mg}, 0.085 \mathrm{mmol})$ in $\mathrm{CH}_{3} \mathrm{OH}$ was added $20 \%$ wt $\mathrm{Pd}(\mathrm{OH})_{2} / \mathrm{C}(10 \mathrm{mg})$. The suspension was 
degassed under vacuum and saturated with $\mathrm{H}_{2}$ in a 1 atm balloon. The reaction mixture was stirred overnight. When the starting material was consumed, as determined by TLC analysis, the catalyst was filtered off. The filtrate was concentrated under reduced pressure to give 14 (19 $\mathrm{mg}$, $100 \%)$.

Data for 14 (Figures S28-S30). ${ }^{1} \mathrm{H}$ NMR (500 MHz, $\left.\mathrm{D}_{2} \mathrm{O}\right): \delta 5.94\left(\mathrm{t}^{2}{ }^{2} \mathrm{H}_{\mathrm{H}-\mathrm{I}, \mathrm{F}}=54 \mathrm{~Hz}, 1 \mathrm{H}, \mathrm{H}-1\right), 3.93-3.70(\mathrm{~m}, 4 \mathrm{H})$, $3.68(\mathrm{~d}, J=10 \mathrm{~Hz}, 1 \mathrm{H})$, and $3.51(\mathrm{t}, J=9 \mathrm{~Hz}, 1 \mathrm{H}) .{ }^{19} \mathrm{~F}\left\{{ }^{1} \mathrm{H}\right\}$ $\operatorname{NMR}\left(282 \mathrm{MHz}, \mathrm{D}_{2} \mathrm{O}\right): \delta-133.2\left(\mathrm{~d},{ }^{2} \mathrm{~J}_{\mathrm{Fa}-\mathrm{Fb}}=286 \mathrm{~Hz}\right)$ and $-140.7\left({ }^{2} \mathrm{~J}_{\mathrm{Fa}-\mathrm{Fb}}=286 \mathrm{~Hz}\right) \cdot{ }^{19} \mathrm{~F}$ NMR $\left(282 \mathrm{MHz}, \mathrm{D}_{2} \mathrm{O}\right): \delta$ $-133.2\left(\mathrm{dd},{ }^{2} J_{\mathrm{Fa}, \mathrm{Fb}}=286 \mathrm{~Hz},{ }^{2} J_{\mathrm{Fa}, \mathrm{H}}=54 \mathrm{~Hz}, 1 \mathrm{~F}\right)$ and -140.7 $\left(\mathrm{dd},{ }^{2} J_{\mathrm{Fb}, \mathrm{Fa}}=286 \mathrm{~Hz},{ }^{2} J_{\mathrm{Fb}, \mathrm{H}}=54 \mathrm{~Hz}, 1 \mathrm{~F}\right) .{ }^{13} \mathrm{C}\left\{{ }^{1} \mathrm{H}\right\} \mathrm{NMR}(125$ $\left.\mathrm{MHz}, \mathrm{D}_{2} \mathrm{O}\right): \delta 133.3\left(\mathrm{t},{ }^{1} J_{\mathrm{C}-1, \mathrm{~F}}=249 \mathrm{~Hz}, \mathrm{C}-1\right), 94.6\left(\mathrm{t},{ }^{2} J_{\mathrm{C}-2, \mathrm{~F}}=\right.$ $94.6 \mathrm{~Hz}, \mathrm{C}-2$ ), 73.4, 72.8, 70.2, 69.2, and 60.4. HRMS (ESI/ TOF) $m / z:[\mathrm{M}+\mathrm{Na}]^{+}$calcd for $\mathrm{C}_{7} \mathrm{H}_{12} \mathrm{O}_{6} \mathrm{~F}_{2} \mathrm{Na}, 253.0494$; found, 253.0493 .

Following the general procedure, 3 ( $17 \mathrm{mg}, 92 \%$ yield) was obtained from compound $14(13.8 \mathrm{mg}, 60 \mu \mathrm{M}), \mathrm{MgCl}_{2}(122$ $\mathrm{mg}, 600 \mu \mathrm{M})$, ATP $(200 \mathrm{mM}, 600 \mu \mathrm{L})$, Glk $\left(28 \mathrm{mg} \mathrm{mL}^{-1}, 110\right.$ $\mu \mathrm{L})$, and Tris- $\mathrm{HCl}(50 \mathrm{mM}, 3290 \mu \mathrm{L}, \mathrm{pH} 7.5)$.

Data for 3 (Figures S31-S34). ${ }^{1} \mathrm{H}$ NMR (500 MHz, $\left.\mathrm{D}_{2} \mathrm{O}\right)$ : $\delta 5.86\left(\mathrm{t},{ }^{2} J_{\mathrm{H} 1, \mathrm{~F}}=55.0 \mathrm{~Hz}, 1 \mathrm{H}\right), 4.05-4.00(\mathrm{~m}, 1 \mathrm{H}), 3.98-3.95$ $(\mathrm{m}, 1 \mathrm{H}), 3.89-3.87(\mathrm{~m}, 1 \mathrm{H}), 3.74-3.69(\mathrm{~m}, 1 \mathrm{H}), 3.62-3.60$ $(\mathrm{m}, 1 \mathrm{H})$, and $3.52(\mathrm{t}, J=10.0 \mathrm{~Hz}, 1 \mathrm{H}) .{ }^{19} \mathrm{~F}\left\{{ }^{1} \mathrm{H}\right\}$ NMR $(470$ $\left.\mathrm{MHz}, \mathrm{D}_{2} \mathrm{O}\right): \delta-133.3\left(\mathrm{~d},{ }^{2} J_{\mathrm{F}, \mathrm{F}}=286.7 \mathrm{~Hz}\right)$ and $-141.1(\mathrm{~d}$, $\left.{ }^{2} J_{\mathrm{F}, \mathrm{F}}=286.7 \mathrm{~Hz}\right) .{ }^{19} \mathrm{~F} \mathrm{NMR}\left(470 \mathrm{MHz}, \mathrm{D}_{2} \mathrm{O}\right): \delta-133.3(\mathrm{dd}$, $\left.{ }^{2} J_{\mathrm{H}, \mathrm{F}}=54.4 \mathrm{~Hz},{ }^{2} J_{\mathrm{F}, \mathrm{F}}=286.7 \mathrm{~Hz}\right)$ and $-141.1\left(\mathrm{dd},{ }^{2} J_{\mathrm{H}, \mathrm{F}}=54.4\right.$ $\left.\mathrm{Hz},{ }^{2} J_{\mathrm{F}, \mathrm{F}}=286.7 \mathrm{~Hz}\right) \cdot{ }^{31} \mathrm{P}\left\{{ }^{1} \mathrm{H}\right\} \operatorname{NMR}\left(202 \mathrm{MHz}, \mathrm{D}_{2} \mathrm{O}\right): \delta 3.1$. ${ }^{13} \mathrm{C}\left\{{ }^{1} \mathrm{H}\right\} \operatorname{NMR}\left(125 \mathrm{MHz}, \mathrm{D}_{2} \mathrm{O}\right): \delta 113.2\left(\mathrm{t},{ }^{1} J_{\mathrm{C}-1, \mathrm{~F}}=247.5\right.$ $\mathrm{Hz}, \mathrm{C}-1), 94.8\left(\mathrm{t},{ }^{2} \mathrm{~J}_{\mathrm{C}-2, \mathrm{~F}}=21.3 \mathrm{~Hz}, \mathrm{C}-2\right), 73.1,72.3\left(\mathrm{~d},{ }^{2} \mathrm{~J}_{\mathrm{C}-7, \mathrm{P}}=\right.$ $7.5 \mathrm{~Hz}, \mathrm{C}-7), 70.3,68.8$, and $62.9\left(\mathrm{~d},{ }^{3} J_{\mathrm{C}-6, \mathrm{P}}=3.9 \mathrm{~Hz}, \mathrm{C}-6\right)$, HRMS $\left(\mathrm{ESI}^{-}\right)$: found $[\mathrm{M}-\mathrm{H}]^{-}, 309.0181, \mathrm{C}_{7} \mathrm{H}_{12} \mathrm{~F}_{2} \mathrm{O}_{9} \mathrm{P}$; requires $[\mathrm{M}-\mathrm{H}]^{-}, 309.0192$.

1-Deoxy-1-trifluoro- $\alpha$-D-gluco-heptulose 7-Phosphate (4). Compound 11 was prepared by treatment of lactone 5 with $\mathrm{TMSCF}_{3}$ in THF, according to a literature method. ${ }^{28}$ Data for 11 (Figure S35): ${ }^{19} \mathrm{~F}$ NMR (470 MHz, $\left.\mathrm{D}_{2} \mathrm{O}\right): \delta$-83.4. This data is consistent with that reported. ${ }^{28}$

To a solution of 11 (110 mg, $0.181 \mathrm{mmol})$ in $\mathrm{CH}_{3} \mathrm{OH}, \mathrm{Pd} /$ $\mathrm{C}(20 \mathrm{mg})$ was added. The suspension was degassed under vacuum and saturated with $\mathrm{H}_{2}$ in a Parr shaker at 60 psi pressure. This reaction mixture was shaken for 3 days until the starting material disappeared, as determined by TLC analysis. The catalyst was filtered off, and the filtrate was concentrated under reduced pressure to give $\mathbf{1 5}$ (44.4 $\mathrm{mg}, 100 \%)$.

Data for 15 (Figures S36-S38). ${ }^{1} \mathrm{H}$ NMR (500 MHz, $\left.\mathrm{D}_{2} \mathrm{O}\right): \delta 3.76-3.67(\mathrm{~m}, 3 \mathrm{H}), 3.63-3.62(\mathrm{~m}, 2 \mathrm{H})$, and $3.41-$ $3.38(\mathrm{~m}, 1 \mathrm{H}) .{ }^{19} \mathrm{~F}\left\{{ }^{1} \mathrm{H}\right\} \mathrm{NMR}\left(470 \mathrm{MHz}, \mathrm{D}_{2} \mathrm{O}\right): \delta-82.5(\mathrm{~s})$. ${ }^{19} \mathrm{~F}$ NMR (470 MHz, $\left.\mathrm{D}_{2} \mathrm{O}\right): \delta-82.5(\mathrm{~s}) .{ }^{13} \mathrm{C}\left\{{ }^{1} \mathrm{H}\right\}$ NMR (125 $\left.\mathrm{MHz}, \mathrm{D}_{2} \mathrm{O}\right): \delta 122.3\left(\mathrm{q},{ }^{1} J_{\mathrm{C}-1, \mathrm{~F}}=285.6 \mathrm{~Hz}, \mathrm{C}-1\right), 94.5(\mathrm{q}$, $\left.{ }^{2} J_{\mathrm{C}-2, \mathrm{~F}}=30.1 \mathrm{~Hz}, \mathrm{C}-2\right)$, 73.3, 73.0, 70.0, 68.7, and 60.0, HRMS $\left(\mathrm{ESI}^{+}\right)$: found $[\mathrm{M}+\mathrm{Na}]^{+}, 271.0406, \mathrm{C}_{7} \mathrm{H}_{11} \mathrm{~F}_{3} \mathrm{NaO}_{6}$; requires $[\mathrm{M}+\mathrm{Na}]^{+}, 271.0400$.

Following the general procedure, $4(15.7 \mathrm{mg}$, 98\%) was obtained from compound $15(12.5 \mathrm{mg}, 50 \mu \mathrm{M}), \mathrm{MgCl}_{2}(102$ $\mathrm{mg}, 500 \mu \mathrm{M})$, ATP $(200 \mathrm{mM}, 500 \mu \mathrm{L})$, Glk $\left(28 \mathrm{mg} \mathrm{mL}^{-1}, 110\right.$ $\mu \mathrm{L})$, and Tris- $\mathrm{HCl}(50 \mathrm{mM}, 3390 \mu \mathrm{L}, \mathrm{pH} 7.5)$.

Data for 4 (Figures S39-S42). ${ }^{1} \mathrm{H}$ NMR (500 MHz, $\left.\mathrm{D}_{2} \mathrm{O}\right)$ : $\delta 4.034$ (ddd, $J=12.0,7.5$ and $4.5 \mathrm{~Hz}, 1 \mathrm{H}$ ), 3.98 (ddd, $J=7.6$, 5.7 and $1.9 \mathrm{~Hz}, 1 \mathrm{H}), 3.89-3.86(\mathrm{~m}, 1 \mathrm{H}), 3.73-3.68(\mathrm{~m}, 2 \mathrm{H})$, and 3.59-3.55 (m, 1H). ${ }^{19} \mathrm{~F}\left\{{ }^{1} \mathrm{H}\right\}$ NMR (470 MHz, $\left.\mathrm{D}_{2} \mathrm{O}\right): \delta$
-82.4. ${ }^{19} \mathrm{~F}$ NMR (470 MHz, $\left.\mathrm{D}_{2} \mathrm{O}\right): \delta-82.4 .{ }^{31} \mathrm{P}\left\{{ }^{1} \mathrm{H}\right\}$ NMR $\left(202 \mathrm{MHz}, \mathrm{D}_{2} \mathrm{O}\right): \delta 2.8 .{ }^{13} \mathrm{C}\left\{{ }^{1} \mathrm{H}\right\} \operatorname{NMR}\left(125 \mathrm{MHz}, \mathrm{D}_{2} \mathrm{O}\right): \delta$ $122.4\left(\mathrm{q},{ }^{1} J_{\mathrm{C}-1, \mathrm{~F}}=286.3 \mathrm{~Hz}, \mathrm{C}-1\right), 94.8\left(\mathrm{q},{ }^{2} J_{\mathrm{C}-2, \mathrm{~F}}=31.3 \mathrm{~Hz}, \mathrm{C}-\right.$ 1), 73.1, $72.6\left(\mathrm{~d},{ }^{2} J_{\mathrm{C}-7, \mathrm{P}}=7.5 \mathrm{~Hz}, \mathrm{C}-7\right), 70.2,68.6$, and $62.9(\mathrm{~d}$, $\left.{ }^{3} J_{\mathrm{C}-7, \mathrm{P}}=4.0 \mathrm{~Hz}, \mathrm{C}-6\right)$. HRMS $\left(\mathrm{ESI}^{-}\right)$: found $[\mathrm{M}-\mathrm{H}]^{-}$, 327.0103, $\mathrm{C}_{7} \mathrm{H}_{11} \mathrm{~F}_{3} \mathrm{O}_{9} \mathrm{P}$; requires $[\mathrm{M}-\mathrm{H}]^{-}, 327.0098$.

Protein Overexpression and Purification. $\beta$ PGM, $\alpha \mathrm{PMM} / \mathrm{PGM}$, and Glk were overexpressed, purified, and quantified as previously described. ${ }^{40}$ The gene for XcPGM was commercially synthesized (GenScript) and inserted into the pET-14B vector with an N-terminal tobacco etch virus (TEV) protease cleavage site and $\mathrm{His}_{6}$-affinity tag. The plasmid was transformed into E. coli BL31(DE3) for recombinant protein expression. Cultures were grown at $37{ }^{\circ} \mathrm{C}$ in LB media, supplemented with $0.1 \mathrm{mg} \mathrm{mL}{ }^{-1}$ of ampicillin to an $\mathrm{OD}_{600}$ of $0.8-1.0$. Cultures were then cooled at $4{ }^{\circ} \mathrm{C}$ for at least $30 \mathrm{~min}$, whereby, isopropyl 1-thio- $\beta$-D-galactopyranoside (final concentration $0.4 \mathrm{mM}$ ) was added, and the cultures were incubated for $\sim 18 \mathrm{~h}$ at $18{ }^{\circ} \mathrm{C}$. Cell pellets were collected by centrifugation, flash frozen in liquid $\mathrm{N}_{2}$, and stored at $-80^{\circ} \mathrm{C}$.

For purification, frozen cell pellets were resuspended in buffer A (20 mM sodium phosphate, $0.3 \mathrm{M} \mathrm{NaCl}, \mathrm{pH} 7.8$ ) containing $14.4 \mathrm{mM} \beta$-mercaptoethanol, $0.5 \mathrm{mM}$ phenylmethylsulfonyl fluoride (PMSF), $0.5 \mathrm{mM}$ tosyllysine chloromethyl ketone, $2 \mathrm{mM} \mathrm{CaCl}_{2}, 2 \mathrm{mM} \mathrm{MgSO}_{4}$, and $10 \mu \mathrm{g} / \mathrm{mL}$ of DNase. A French press was used for cell lysis. The soluble fraction containing XcPGM was obtained through centrifugation. Protamine sulfate was added at $5 \mathrm{mg} / \mathrm{g}$ of cell pellet over $15 \mathrm{~min}$, stirred for $30 \mathrm{~min}$, and centrifuged. The supernatant was mixed with $\mathrm{Ni}^{2+}$ affinity resin (His-Select, Sigma), which had been previously equilibrated in buffer $\mathrm{A}$, and incubated for $30 \mathrm{~min}$ on a two-way orbital rocker. The mixture was transferred into a gravity-packed column and washed with buffer A containing $5 \mathrm{mM}$ imidazole, $\mathrm{pH}$ 7.8. Protein was eluted using buffer A supplemented with $250 \mathrm{mM}$ imidazole, $\mathrm{pH}$ 7.8. The purified protein was dialyzed into a solution of 50 $\mathrm{mM}$ Tris $\mathrm{HCl}, \mathrm{pH} 8.0$, with $0.3 \mathrm{M} \mathrm{NaCl}$. TEV protease was added to the purified protein at $5 \% \mathrm{w} / \mathrm{w}$. The mixture was incubated at room temperature for $4 \mathrm{~h}$ and left overnight at 4 ${ }^{\circ} \mathrm{C}$. The mixture was then incubated with pre-equilibrated $\mathrm{Ni}^{2+}$ affinity resin for $30 \mathrm{~min}$. Cleaved XcPGM was retrieved in the flow-through and dialyzed into $20 \mathrm{mM}$ Tris $\mathrm{HCl}, \mathrm{pH} 7.4$, with $0.3 \mathrm{M} \mathrm{NaCl}$ and concentrated to $\sim 11 \mathrm{mg} \mathrm{mL}^{-1}$. The purified protein was flash-frozen in liquid nitrogen and stored at -80 ${ }^{\circ} \mathrm{C}$. Total yield of protein from $1 \mathrm{~L}$ of cell culture was $\sim 80 \mathrm{mg}$.

Crystallization and Complex Formation. Purified XcPGM was initially screened for crystallization via hangingdrop vapor diffusion using the previously published conditions, ${ }^{37}$ which did not yield data collection quality crystals. Several commercial screens were then utilized, including Morpheus 1 and Hampton Crystal Screen 1. Optimizations were set up around several hits, and a final condition of $22 \%$ PEG 8000, 0.2 $\mathrm{M} \mathrm{MgCl}_{2}, 0.1 \mathrm{M}$ HEPES, pH 7.5, was identified and used for all crystals described herein. Crystals typically grew overnight at $18{ }^{\circ} \mathrm{C}$. Despite the different crystallization conditions, the XcPGM crystals reported here were isomorphous with those published previously (Table S2).

The CH3G6P complex was obtained by soaking crystals with high concentrations of the ligand. The ligand solution at $\sim 20 \mathrm{mM}$ was prepared in the crystallization buffer supplemented with cryoprotectant of 25-30\% PEG 3350. Crystals were removed from the drop, dipped quickly into the 
ligand solution, and immediately flash-cooled and stored in liquid $\mathrm{N}_{2}$.

X-ray Diffraction Data Collection and Refinement. Diffraction data were collected at a wavelength of $1.00003 \AA$ from single crystals on beamline 4.2.2 of the advanced light source using a Taurus-1 CMOS detector in the shutterless mode. Data were processed using $\mathrm{XDS}^{41}$ and AIMLESS ${ }^{42}$ in CCP4i. ${ }^{43}$ Data processing statistics are listed in Table S1 (see the Supporting Information). Values of $\mathrm{CC}_{1 / 2}>0.30^{44}$ and $R_{\text {pim }}{ }^{45}$ were used to determine the high resolution cutoff due to the large number of images (900-3600 per data set) and high redundancy obtained with the shutterless data collection.

Crystallographic refinement calculations were initiated using coordinates of apo-XcPGM (PDB ID: 5BMN). Refinement was performed with PHENIX; ${ }^{46}$ progress was monitored by following $R_{\text {free, }}$ with $5 \%$ of each data-set set aside for cross validation. The B-factor model consisted of an isotropic Bfactor for each atom; TLS refinement was used as automated in PHENIX. Occupancy of the ligand was also refined and converged at 0.82 . COOT $^{47}$ was used for model building. The structures were validated using MolProbity, ${ }^{48}$ and the refinement statistics are listed in Table S1 (see the Supporting Information). Likely hydrogen bond criteria and lengths were determined by CONTACT in CCP4. ${ }^{43}$ Structural figures were prepared with PYMOL. ${ }^{49}$ The coordinates and structure factor amplitudes have been deposited in the PDB under the accession numbers listed in Table S1 (see the Supporting Information).

Kinetic Inhibition Assays ( $\mathrm{IC}_{50}$ Determination) of Analogues 1-4 Against $\alpha$ PMM/PGM and $\beta$ PGM. $I C_{50}$ Determination of $\beta P G M$. Assays were carried out in a final volume of $200 \mu \mathrm{L}$ containing $50 \mathrm{mM}$ HEPES pH 7.2, $2 \mathrm{mM}$ $\mathrm{MgCl}_{2}, 0.5 \mathrm{mM} \mathrm{NAD}{ }^{+}, 5 \mathrm{U} / \mathrm{mL}$ G6PDH, $150 \mu \mathrm{M} \alpha \mathrm{F} 16 \mathrm{BP}, 10$ $\mu \mathrm{M} \beta \mathrm{G} 1 \mathrm{P}, 83 \mathrm{nM} \beta \mathrm{PGM}$, and 5-1000 $\mu \mathrm{M}$ inhibitor (1-4). $\beta \mathrm{PGM}$ was pre-incubated with $\alpha \mathrm{F} 16 \mathrm{BP}$ for $30-45 \mathrm{~min}$. Reactions were initiated by addition of the pre-incubated $\beta$ PGM/F16BP mixture to the remaining reaction components.

$I C_{50}$ Determination of $\alpha P M M / P G M$. Assays were conducted in a final volume of $200 \mu \mathrm{L}$ containing $50 \mathrm{mM}$ MOPS buffer $\mathrm{pH} 7.4,3.6 \mathrm{mM} \mathrm{MgCl}_{2}, 0.9 \mathrm{mM} \mathrm{NAD}{ }^{+}, 1 \mathrm{mM}$ EDTA, $1 \mathrm{mM}$ DTT, $5 \mathrm{U} / \mathrm{mL}$ G6PDH, $2 \mu \mathrm{M} \alpha \mathrm{G} 16 \mathrm{P}, 20 \mu \mathrm{M} \alpha \mathrm{G} 1 \mathrm{P}, 0.242$ $\mu \mathrm{M} \alpha \mathrm{PGM} / \mathrm{PMM}$, and 5-1000 $\mu \mathrm{M}$ inhibitor (1-4). $\alpha \mathrm{PMM} /$ PGM was pre-incubated with $\alpha \mathrm{G} 16 \mathrm{P}$ for $1-1.5 \mathrm{~h}$. Reactions were initiated by addition of the pre-incubated $\alpha \mathrm{PMM} / \mathrm{PGM} /$ $\alpha \mathrm{G} 16 \mathrm{P}$ mixture to the remaining reaction components.

\section{ASSOCIATED CONTENT}

\section{S Supporting Information}

The Supporting Information is available free of charge on the ACS Publications website at DOI: 10.1021/acsomega.9b00008.

${ }^{19} \mathrm{~F}\left\{{ }^{1} \mathrm{H}\right\}$ NMR and ${ }^{31} \mathrm{P}\left\{{ }^{1} \mathrm{H}\right\}$ NMR spectra comparison of phosphonate 6 and phosphate 7, the activity (plots) of $\alpha \mathrm{PMM} / \mathrm{PGM}$ and $\beta$ PGM in response to inhibitors (14), sequence alignment of $X$. citri PGM and P. aeruginosa PMM/PGM, X-ray data collection and refinement statistics for 1 complex, polder omit map, characterization data, and NMR spectra of new compounds (1-4, 7, 12, 14 and 15) (PDF)

\section{AUTHOR INFORMATION}

\section{Corresponding Authors}

*E-mail: beamerl@missouri.edu (L.J.B.).

*E-mail: David.Jakeman@dal.ca (D.L.J.).

ORCID

Lesa J. Beamer: 0000-0001-5689-200X

David L. Jakeman: 0000-0003-3002-3388

\section{Author Contributions}

II S.M.W., A.D.G., and A.F.V. contributed equally.

Notes

The authors declare no competing financial interest.

\section{ACKNOWLEDGMENTS}

CIHR, NSERC, MITACS, and the NSF (MCB-1409898) are thanked for funding support. We thank Stephen G. Withers (University of British Columbia, BC, Canada) for the gift of the Glk plasmid.

\section{REFERENCES}

(1) Jacobsen, A.; Thiem, J. Contemporary Syntheses of 2Ketoheptoses and Derivatives. Curr. Org. Chem. 2014, 18, 28332841.

(2) (a) Blomberg, B. A.; Codreanu, I.; Cheng, G.; Werner, T. J.; Alavi, A. Beta-Cell Imaging: Call for Evidence-Based and Scientific Approach. Mol. Imaging Biol. 2013, 15, 123-130. (b) Tiedge, M. Inside the pancreas: progress and challenges of human beta cell mass quantification. Diabetologia 2014, 57, 856-859. (c) Jodal, A.; Schibli, $\mathrm{R}$; Béhé, M. Targets and probes for non-invasive imaging of $\beta$-cells. Eur. J. Nucl. Med. Mol. Imaging 2017, 44, 712-727.

(3) Malaisse, W. J.; Zhang, Y.; Louchami, K.; Sharma, S.; Dresselaers, T.; Himmelreich, U.; Novotny, G. W.; MandrupPoulsen, T.; Waschke, D.; Leshch, Y.; Thimm, J.; Thiem, J.; Sener, A. 19F-heptuloses as tools for the non-invasive imaging of GLUT2expressing cells. Arch. Biochem. Biophys. 2012, 517, 138-143.

(4) Chen, Y.; Wang, X.; Wang, J.; Yang, Y. Synthesis of D-mannoheptulose via a cascade aldol/hemiketalization reaction. Beilstein J. Org. Chem. 2017, 13, 795-799.

(5) (a) Subrizi, F.; Cárdenas-Fernández, M.; Lye, G. J.; Ward, J. M.; Dalby, P. A.; Sheppard, T. D.; Hailes, H. C. Transketolase catalysed upgrading of 1-arabinose: the one-step stereoselective synthesis of 1 gluco-heptulose. Green Chem. 2016, 18, 3158-3165. (b) Yang, J.; Zhu, Y.; Li, J.; Men, Y.; Sun, Y.; Ma, Y. Biosynthesis of rare ketoses through constructing a recombination pathway in an engineeredCorynebacterium glutamicum. Biotechnol. Bioeng. 2015, 112, 168180.

(6) Kim, J.-H.; Resende, R.; Wennekes, T.; Chen, H.-M.; Bance, N.; Buchini, S.; Watts, A. G.; Pilling, P.; Streltsov, V. A.; Petric, M.; Liggins, R.; Barrett, S.; McKimm-Breschkin, J. L.; Niikura, M.; Withers, S. G. Mechanism-Based Covalent Neuraminidase Inhibitors with Broad-Spectrum Influenza Antiviral Activity. Science 2013, 340, $71-75$.

(7) Onega, M.; Winkler, M.; O'Hagan, D. Fluorinase: a tool for the synthesis of 18F-labeled sugars and nucleosides for PET. Future Med. Chem. 2009, 1, 865-873.

(8) Matei, E.; André, S.; Glinschert, A.; Infantino, A. S.; Oscarson, S.; Gabius, H.-J.; Gronenborn, A. M. Fluorinated Carbohydrates as Lectin Ligands: Dissecting Glycan-Cyanovirin Interactions by Using 19F NMR Spectroscopy. Chem.-Eur. J. 2013, 19, 5364-5374.

(9) Linclau, B.; Wang, Z.; Compain, G.; Paumelle, V.; Fontenelle, C. Q.; Wells, N.; Weymouth-Wilson, A. Investigating the Influence of (Deoxy)fluorination on the Lipophilicity of Non-UV-Active Fluorinated Alkanols and Carbohydrates by a New log P Determination Method. Angew. Chem., Int. Ed. 2016, 55, 674-678.

(10) Whitehouse, D. B.; Tomkins, J.; Lovegrove, J. U.; Hopkinson, D. A.; McMillan, W. O. A phylogenetic approach to the identification of phosphoglucomutase genes. Mol. Biol. Evol. 1998, 15, 456-462. 
(11) Lahiri, S. D.; Zhang, G.; Dunaway-Mariano, D.; Allen, K. N. Caught in the Act: The Structure of Phosphorylated $\beta$-Phosphoglucomutase from Lactococcus lactis. Biochemistry 2002, 41, 8351-8359.

(12) Levander, F.; Andersson, U.; Radstrom, P. Physiological Role of $\beta$-Phosphoglucomutase inLactococcus lactis. Appl. Environ. Microbiol. 2001, 67, 4546-4553.

(13) Stiers, K. M.; Muenks, A. G.; Beamer, L. J. Biology, Mechanism, and Structure of Enzymes in the $\alpha$-d-Phosphohexomutase Superfamily. Advances in Protein Chemistry and Structural Biology; Academic Press, 2017; Vol. 109, pp 265-304.

(14) Regni, C.; Tipton, P. A.; Beamer, L. J. Crystal Structure of PMM/PGM. Structure 2002, 10, 269-279.

(15) Willyard, C. The drug-resistant bacteria that pose the greatest health threats. Nature 2017, 543, 15.

(16) Huang, Y. L.; Ebner, K. E. Inhibition of phosphoglucomutase by galactose 1,6-diphosphate. Experientia 1969, 25, 917-918.

(17) Galloway, C. M.; Dugger, W. M.; Black, C. C. Fructose 2,6Bisphosphate Inhibition of Phosphoglucomutase. Plant Physiol. 1988, $88,980-982$.

(18) Naught, L. E.; Tipton, P. A. Kinetic Mechanism and $\mathrm{pH}$ Dependence of the Kinetic Parameters of Pseudomonas aeruginosa Phosphomannomutase/Phosphoglucomutase. Arch. Biochem. Biophys. 2001, 396, 111-118.

(19) Percival, M. D.; Withers, S. G. Synthesis and testing of sugar phosphofluoridates and cyclic phosphates as inhibitors of phosphoglucomutase. J. Org. Chem. 1992, 57, 811-817.

(20) Kim, S. C.; Raushel, F. M. Mechanism-based inactivation of rabbit muscle phosphoglucomutase by nojirimycin 6-phosphate. Biochemistry 1988, 27, 7328-7332.

(21) Percival, M. D.; Doherty, K.; Gresser, M. J. Inhibition of phosphoglucomutase by vanadate. Biochemistry 1990, 29, 2764-2769.

(22) Jin, Y.; Richards, N. G.; Waltho, J. P.; Blackburn, G. M. Metal Fluorides as Analogues for Studies on Phosphoryl Transfer Enzymes. Angew. Chem., Int. Ed. 2017, 56, 4110-4128.

(23) (a) Baxter, N. J.; Bowler, M. W.; Alizadeh, T.; Cliff, M. J.; Hounslow, A. M.; Wu, B.; Berkowitz, D. B.; Williams, N. H.; Blackburn, G. M.; Waltho, J. P. Atomic details of near-transition state conformers for enzyme phosphoryl transfer revealed by Formula rather than by phosphoranes. Proc. Natl. Acad. Sci. U.S.A. 2010, 107, 4555-4560. (b) Griffin, J. L.; Bowler, M. W.; Baxter, N. J.; Leigh, K. N.; Dannatt, H. R. W.; Hounslow, A. M.; Blackburn, G. M.; Webster, C. E.; Cliff, M. J.; Waltho, J. P. Near attack conformers dominate -phosphoglucomutase complexes where geometry and charge distribution reflect those of substrate. Proc. Natl. Acad. Sci. U.S.A. 2012, 109, 6910-6915.

(24) (a) Jin, Y.; Bhattasali, D.; Pellegrini, E.; Forget, S. M.; Baxter, N. J.; Cliff, M. J.; Bowler, M. W.; Jakeman, D. L.; Blackburn, G. M.; Waltho, J. P. $\alpha$-Fluorophosphonates reveal how a phosphomutase conserves transition state conformation over hexose recognition in its two-step reaction. Proc. Natl. Acad. Sci. U.S.A. 2014, 111, 1238412389. (b) Ampaw, A.; Carroll, M.; von Velsen, J.; Bhattasali, D.; Cohen, A.; Bowler, M. W.; Jakeman, D. L. Observing enzyme ternary transition state analogue complexes by 19F NMR spectroscopy. Chem. Sci. 2017, 8, 8427-8434.

(25) Meyer, D.; Schneider-Fresenius, C.; Horlacher, R.; Peist, R.; Boos, W. Molecular characterization of glucokinase from Escherichia coli K-12. J. Bacteriol. 1997, 179, 1298-1306.

(26) Lay, L.; Nicotra, F.; Panza, L.; Russo, G.; Caneva, E. Synthesis of C-disaccharides through dimerization of exo-glycals. J. Org. Chem. 1992, 57, 1304-1306.

(27) Leshch, Y.; Waschke, D.; Thimm, J.; Thiem, J. d-Gluco-hept-2ulose and Novel Deoxyfluoro Derivatives as Seven-Carbon Analogues of F-Deoxy-d-glucose (FDG). Synthesis 2011, 3871-3877.

(28) Magueur, G.; Crousse, B.; Ourévitch, M.; Bonnet-Delpon, D.; Bégué, J.-P. Fluoro-artemisinins: When a gem-difluoroethylene replaces a carbonyl group. J. Fluorine Chem. 2006, 127, 637-642.

(29) (a) Beier, P.; Alexandrova, A. V.; Zibinsky, M.; Surya Prakash, G. K. Nucleophilic difluoromethylation and difluoromethylenation of aldehydes and ketones using diethyl difluoromethylphosphonate.
Tetrahedron 2008, 64, 10977-10985. (b) Beier, P.; Pohl, R.; Alexandrova, A. An Efficient and Highly Selective Synthesis of (Z)Fluoroenol Phosphates from Hydroxy Difluorophosphonates. Synthesis 2009, 957-962.

(30) Forget, S. M.; Bhattasali, D.; Hart, V. C.; Cameron, T. S.; Syvitski, R. T.; Jakeman, D. L. Synthesis and enzymatic evaluation of ketose phosphonates: the interplay between mutarotation, monofluorination and acidity. Chem. Sci. 2012, 3, 1866-1878.

(31) Liu, X.; Yin, Q.; Yin, J.; Chen, G.; Wang, X.; You, Q.-D.; Chen, Y.-L.; Xiong, B.; Shen, J. Highly Stereoselective Nucleophilic Addition of Difluoromethyl-2-pyridyl Sulfone to Sugar Lactones and Efficient Synthesis of Fluorinated 2-Ketoses. Eur. J. Org. Chem. 2014, 61506154.

(32) Kwan, D. H.; Jin, Y.; Jiang, J.; Chen, H.-M.; Kötzler, M. P.; Overkleeft, H. S.; Davies, G. J.; Withers, S. G. Chemoenzymatic synthesis of 6-phospho-cyclophellitol as a novel probe of 6-phospho$\beta$-glucosidases. FEBS Lett. 2016, 590, 461-468.

(33) (a) Zhang, G.; Dai, J.; Wang, L.; Dunaway-Mariano, D.; Tremblay, L. W.; Allen, K. N. Catalytic Cycling in $\beta$-Phosphoglucomutase: A Kinetic and Structural Analysis. Biochemistry 2005, 44, 9404-9416. (b) Schramm, A. M.; Mehra-Chaudhary, R.; Furdui, C. M.; Beamer, L. J. Backbone Flexibility, Conformational Change, and Catalysis in a Phosphohexomutase fromPseudomonas aeruginosa. Biochemistry 2008, 47, 9154-9162.

(34) Cer, R. Z.; Mudunuri, U.; Stephens, R.; Lebeda, F. J. IC50-toKi: a web-based tool for converting IC50 to Ki values for inhibitors of enzyme activity and ligand binding. Nucleic Acids Res. 2009, 37, W441-W445.

(35) (a) Meanwell, N. A. Fluorine and fluorinated motifs in the design and application of bioisosteres for drug design. J. Med. Chem. 2018, 61, 5822-5880. (b) Kitazume, T.; Yamazaki, T. Experimental methods in organic fluorine chemistry. CRC Press, 1999; Vol. 9.

(36) Huheey, J. E. The Electronegativity of Groups. J. Phys. Chem. 1965, 69, 3284-3291.

(37) Goto, L. S.; Vessoni Alexandrino, A.; Malvessi Pereira, C.; Silva Martins, C.; D’Muniz Pereira, H.; Brandão-Neto, J.; Marques NovoMansur, M. T. Structural and functional characterization of the phosphoglucomutase from Xanthomonas citri subsp. citri. Biochim. Biophys. Acta, Proteins Proteomics 2016, 1864, 1658-1666.

(38) Regni, C.; Naught, L.; Tipton, P. A.; Beamer, L. J. Structural basis of diverse substrate recognition by the enzyme PMM/PGM from P. aeruginosa. Structure 2004, 12, 55-63.

(39) Li, X.; Ohtake, H.; Takahashi, H.; Ikegami, S. A facile synthesis of $1^{\prime}$-C-alkyl- $\alpha$-disaccharides from 1-C-alkyl-hexopyranoses and methyl 1-C-methyl-hexopyranosides. Tetrahedron 2001, 57, 42974309.

(40) Timmons, S. C.; Mosher, R. H.; Knowles, S. A.; Jakeman, D. L. Exploiting Nucleotidylyltransferases To Prepare Sugar Nucleotides. Org. Lett. 2007, 9, 857-860.

(41) Kabsch, W. Xds. Acta Crystallogr., Sect. D: Biol. Crystallogr. 2010, 66, 125-132.

(42) Evans, P. R.; Murshudov, G. N. How good are my data and what is the resolution? Acta Crystallogr., Sect. D: Biol. Crystallogr. 2013, 69, 1204-1214.

(43) Potterton, E.; Briggs, P.; Turkenburg, M.; Dodson, E. A graphical user interface to the CCP4 program suite. Acta Crystallogr., Sect. D: Biol. Crystallogr. 2003, 59, 1131-1137.

(44) Karplus, P. A.; Diederichs, K. Linking crystallographic model and data quality. Science 2012, 336, 1030-1033.

(45) Weiss, M. S. Global indicators of X-ray data quality. J. Appl. Crystallogr. 2001, 34, 130-135.

(46) Adams, P. D.; Afonine, P. V.; Bunkóczi, G.; Chen, V. B.; Davis, I. W.; Echols, N.; Headd, J. J.; Hung, L.-W.; Kapral, G. J.; GrosseKunstleve, R. W.; McCoy, A. J.; Moriarty, N. W.; Oeffner, R.; Read, R. J.; Richardson, D. C.; Richardson, J. S.; Terwilliger, T. C.; Zwart, P. H. PHENIX: a comprehensive Python-based system for macromolecular structure solution. Acta Crystallogr., Sect. D: Biol. Crystallogr. 2010, 66, 213-221. 
(47) Emsley, P.; Cowtan, K. Coot: model-building tools for molecular graphics. Acta Crystallogr., Sect. D: Biol. Crystallogr. 2004, 60, 2126-2132.

(48) Chen, V. B.; Arendall, W. B.; Headd, J. J.; Keedy, D. A.; Immormino, R. M.; Kapral, G. J.; Murray, L. W.; Richardson, J. S.; Richardson, D. C. MolProbity: all-atom structure validation for macromolecular crystallography. Acta Crystallogr., Sect. D: Biol. Crystallogr. 2010, 66, 12-21.

(49) Stierand, K.; Rarey, M. Drawing the PDB: Protein-Ligand Complexes in Two Dimensions. ACS Med. Chem. Lett. 2010, 1, 540545 . 